\title{
Estimation of Occupational Stress Index Score Among King Abdulaziz University Students
}

\author{
Ijaz Ahmad, Mohsin Abbas, Mansour A. Balkhyour*, Tarek M. Abokhashabah \\ Department of Environmental Science, Faculty of Meteorology, King Abdulaziz University, Jeddah, \\ Saudi Arabia.
}

\begin{abstract}
Stress is our body's way of responding to any kind of demand or threat. It can start with simply too much pressure. To estimate the occupational stress index (OSI) score among King Abdul Aziz University international students a simple questionnaire study, with $100 \%$ response rate, was conducted. KAU has largest number of students in the Kingdom. The study of stress, OSI score and stressors are accepted important tools for career and personality development and highlighting of students' problems.

The English version of OSI questioner (CHS M278/EHS M270: Work and Health; Winter 2004) used and descriptive research approach selected to calculate OSI score. A t-test performed between OSI score for each individual section and their relevant percentages. P values equal or less than 0.05 considered as significant. For data analysis SPSS and Microsoft Excel version 2013 was used.

Total OSI score estimated was 38.3. Main contributing variables are uneasy lab work (32.6\%) and decision-making at work (16.3\%). The others are absence of rest areas, research grants unavailability. Less work pressure, low working experience, summer holidays, regular monthly stipend, fewer responsibilities, relaxing exams schedule, less number of days spent weakly are all reason for low OSI score. Physical working conditions contribute little but accident or injury shows no contribution for OSI score.

Low OSI score proved KAU international students are working in relaxing environment and feel little stress. Such studies are needed to be done on regular basis to evaluate the Kingdom's largest university student's problems and challenges they face.
\end{abstract}

\section{Introduction}

Stress is a process in which our work and environment stimuli places undue strain on humans, which directly or indirectly results in psychological and physiological changes that increase risk of diseases (Belkić, et al., 1994). Occupational stress has been regarded as one of the major health hazard of the modern work environment. It accounts family issues, physical harm and substance abuse (Belkić, et al., 1992; Emdad, et al., 2009). Stress and stressful working conditions are directly related with more accidents during work, less productivity, off days from work and less efficiency. According to a study by Moller et al., (2005) in aetiology of heart diseases, physiological stress plays an important role.

For measuring work stress, occupational stress index (OSI) is an acceptable scale in modern psychological researches. It is widely and effectively used by psychologists and social scientists (Israel, et al., 1996). Work stresses arises are dominant feature of present life having prominent long lasting effects on employees' behaviour, attitude and work productivity. Due to this, systematic studies demand of stress and working environment stressors have risen dramatically. A considerable portion of organization research involves the study of stress relating to job Karasek and Theorell, (2012). For personality development, personal counselling occupational stress assessment is 
also very important. The measurement of occupational stress can be done using different methods, but all methods cannot be used for every work environment and every demographics. The literature survey shows that there is dearth of reliable and valid stress measuring instruments (Latif and Sultana, 2009). For job relating stress measurement a number of different scales have developed but these are case specific and cannot be used generally for every type of sample. Socio economic and demographic variables have much more consideration in such social and psychological studies (Latif and Sultana, 2009; Möller, et al., 2005).

KAU has largest number of students in the Kingdom. The study of stress, OSI score and stressors is accepted important tool for carrier counselling, personality development and highlighting student's problems. To increase students productivity and efficiency such studies are keen importance to pin point their problems and solving them. So they can continue and focus upon just studies and research. The study objective was to estimate Occupational Stress Index score among King Abdulaziz University students.

\section{Research Methodology}

Total 50 Standard English version questioner (CHS M278/EHS M270: Work and Health; Winter 2004) were distributed among Ph.D. and master international students studying in King Abdulaziz University. All the questionnaire were administered personally to all students by visiting their rooms in hostel and in their class rooms. They were given the time of 3 days to complete it conveniently and with ease. The filled questionnaire then were collected back after 3 days. The response score was $100 \%$. The students mainly have academic and research related activities, they are studying in different semesters. Some are working on research while others are just studying course work. There are local as well as international students from different countries. Mean score was calculated for all the questions and OSI percentage to each section of the OSI questioner was calculated. A t-test performed between OSI score for each individual section and their relevant percentages. $\mathrm{P}$ values equal or less than 0.05 was considered as significant. The data were processed and tabulated, and figures were produced in Microsoft Excel version 2013.

\section{Questioner}

The English version of OSI questioner (CHS M278/EHS M270: Work and Health; Winter 2004) used developed by The Centre for Social Epidemiology Marina Del Rey, Los Angeles County, California. The questioner has 12 sections and total 65 questions mentioned in table 1.

Table 1.

\begin{tabular}{|c|l|}
\hline & Occupational Stress Variables \\
\hline A & Occupation details \\
\hline B & Work hours and scheduling \\
\hline C & Mode of Payment and Evaluation \\
\hline D & Physical Working Conditions \\
\hline E & Work Accidents and Injuries \\
\hline F & Time Pressure at Work \\
\hline G & Problems at Work \\
\hline H & Description of your work tasks \\
\hline I & Decision-making at work \\
\hline J & Interactions with People and with Machines \\
\hline K & Recent changes in your working conditions \\
\hline L & Open ended questions about students research \\
\hline
\end{tabular}

\section{Osi Questioner Scale}

OSI scale based on standard validated questionnaire measures the extent of stress, the occupational group perceives from different stressors during work. There are different types of answering words used in questioner and in random order as well so to put single criteria like "Yes" or "No" based on " 1 " and " 0 " digital value is not compatible to deal the questioner results. For questions 1, 3, 5 and 6 which are mainly about the times (years, months or hours) the results were calculated 
separately and used collected values but did not use the digital values to elaborate results. All questions, which have answers "No", "Never", "None”, "Rarely never” and "Rarely or never", were assigned " 0 " values in the calculations. All questions which have answer "Yes" value " 1 " was assigned. To evaluate OSI score values for questions other than answered yes and No, "Likert scale" was used. For example in section "problems at work" question 29; the information and instructions delegated to you are clear?

a. No, these are unclear (1)

b. Yes, (2)

c. No, sometimes clear some time not (3)

In the answers from a to $\mathrm{c}$ the statement is showing the increasing contribution for the development of occupational stress among students so we put values in increasing order as 1,2 and 3 .

As above mentioned that some answer are random means the approach is not in continuous order in the questioner so we assigned decreasing sore values in the calculations. For example, in section, “decision-making at work" question no. 46; the values were assigned as shows below.

46. Do you assess a given situation rapidly or make quick decisions?

a. Yes, (2)

b. Occasionally (1)

c. No, rarely or never. (0)

The last part of questioner is about open-ended questions about your current work; we did not calculate any values due to the diversity of answers by the respondents and made discussions generally.

\section{Results and Discussion}

Mean OSI score found 38.3 among students. Working hours, scheduling and work experience results shown in figure 1 . Total number of working years and total working experience on current job found near to four averagely. Despite eight hours, working in a working day as standardized but less time at working site has been spent by students may be due to offsite research activities. The number of days per week spend by workers also less than (mean 4.6) allocated days by university.

Occupational stress variables and their relevant score shown in table 2. Section G about the problems at work contribute for OSI more than any other section. Decisions making at work (I) is another section of occupational stress variables, which contribute more than 5 digit score for OSI score.

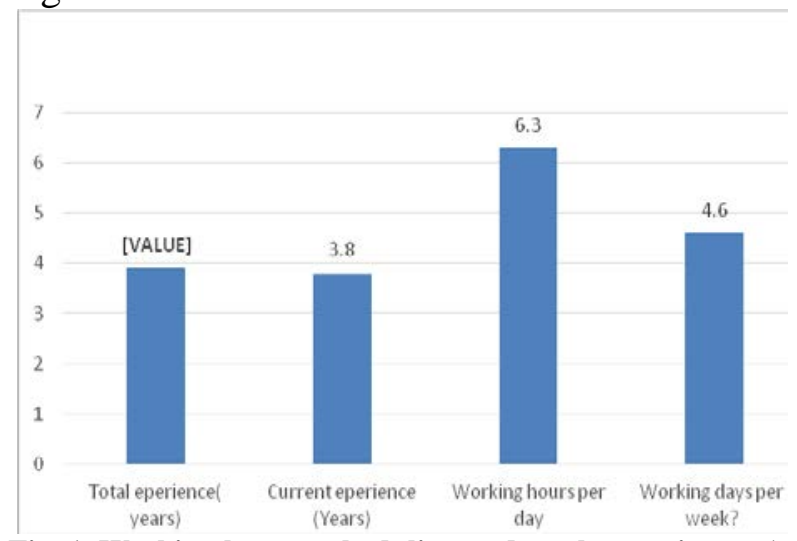

Fig. 1. Working hours, scheduling and work experiences (tTest 3.5, P value 0.03).

Table 2. Occupational Stress Variables OSI score.

\begin{tabular}{|c|c|c|}
\hline Sections & $\begin{array}{l}\text { Occupational Stress Variables } \\
\text { OSI score }\end{array}$ & $\begin{array}{l}\text { OSI } \\
\text { Score }\end{array}$ \\
\hline A & Occupation details & 0.3 \\
\hline B & $\begin{array}{l}\text { Work hours and scheduling } \\
\text { Mode of Payment and }\end{array}$ & 2.8 \\
\hline $\mathrm{C}$ & Evaluation & 2.0 \\
\hline $\mathrm{D}$ & Physical Working Conditions & 4.0 \\
\hline $\mathrm{E}$ & Work Accidents and Injuries & 0.0 \\
\hline $\mathrm{F}$ & Time Pressure at Work & 3.8 \\
\hline G & Problems at Work & 12.5 \\
\hline $\mathrm{H}$ & Description of your work tasks & 2.5 \\
\hline I & $\begin{array}{l}\text { Decision-making at work } \\
\text { Interactions with People and }\end{array}$ & 6.3 \\
\hline $\mathrm{J}$ & $\begin{array}{l}\text { with Machines } \\
\text { Recent changes in your working }\end{array}$ & 3.3 \\
\hline K & $\begin{array}{l}\text { conditions } \\
\text { Open-ended questions about }\end{array}$ & 1.0 \\
\hline $\mathrm{L}$ & students current work & - \\
\hline
\end{tabular}

Except these two sections $G$ and I, no other occupational variables sections significantly 
contribute in OSI as results shown in terms of percentage to the total OSI score for each questioner section. A result of t-test shows that the distribution of OSI scores in each section of questioner are different (t-stat 3.4 and 9.1, $\mathrm{P}$ value 0.03).

\section{Some open-ended questions about student's} current work:

The OSI score of different occupational variables is represented by graph as below.

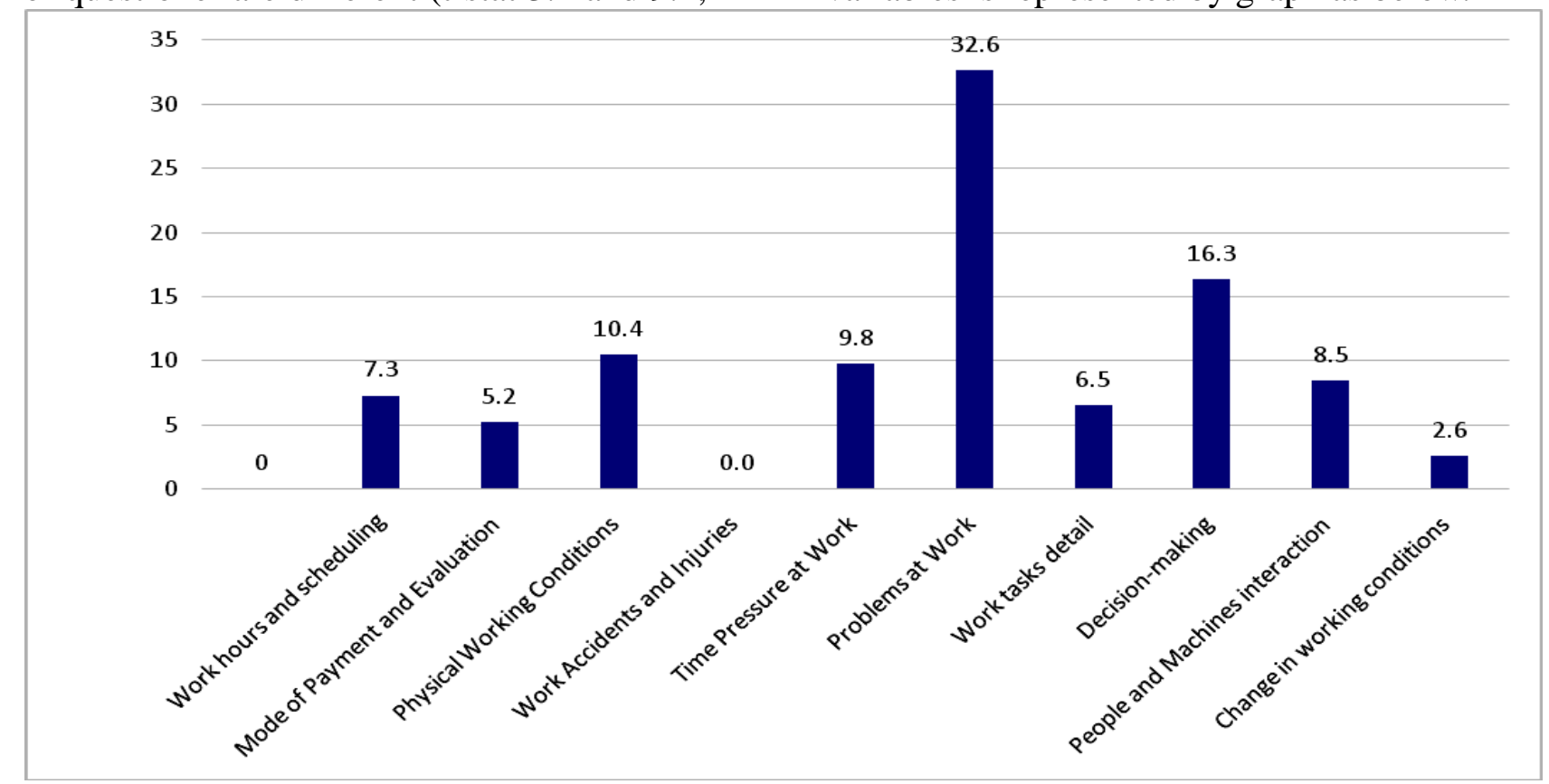

Fig. 2. OSI score of Occupational variables (t-Test 9.1, $P$ value 0.03).

Table 3.

\begin{tabular}{|c|c|c|}
\hline $\begin{array}{l}\text { Q. } \\
\text { No. }\end{array}$ & $\begin{array}{l}\text { Open ended } \\
\text { questions about } \\
\text { students current } \\
\text { work }\end{array}$ & Answers \\
\hline 59 & $\begin{array}{l}\text { How to improve } \\
\text { your working } \\
\text { environment, } \\
\text { suggest? }\end{array}$ & $\begin{array}{l}\text { - Involvement in decisions } \\
\text { - Overcome language barriers } \\
\text { - Systematic approach to work } \\
\text { - Access to chemicals } \\
\text { - Project money }\end{array}$ \\
\hline 60 & $\begin{array}{l}\text { Among all above } \\
\text { which suggestion } \\
\text { do you consider } \\
\text { the most } \\
\text { important? }\end{array}$ & $\begin{array}{l}\text { - Promotion with pay raise } \\
\text { - Uniform Language } \\
\text { - Research grants }\end{array}$ \\
\hline 61 & $\begin{array}{l}\text { What is your jobs } \\
\text { most difficult } \\
\text { aspect? }\end{array}$ & $\begin{array}{l}\text { - No } \\
\text { - Absence of chemicals or instru- } \\
\text { ments } \\
\text { - Official communication }\end{array}$ \\
\hline 62 & $\begin{array}{l}\text { How that difficult } \\
\text { aspect can be } \\
\text { make easy? }\end{array}$ & $\begin{array}{l}\text { - Most responded unanswered } \\
\text { - Language training course }\end{array}$ \\
\hline 63 & $\begin{array}{l}\text { Which part of } \\
\text { your job do you } \\
\text { like most? }\end{array}$ & $\begin{array}{l}\text { - Relaxing job } \\
\text { - Easy work conditions } \\
\text { - Absence of official pressure } \\
\text { - Absence of strictness }\end{array}$ \\
\hline 64 & $\begin{array}{l}\text { What part of your } \\
\text { job you would like } \\
\text { to be continued in }\end{array}$ & $\begin{array}{l}\text { - Yes } \\
\text { - Unanswered } \\
\text { - No specific suggestions } \\
\end{array}$ \\
\hline
\end{tabular}

\begin{tabular}{|l|l|l|}
\hline & $\begin{array}{l}\text { the improved } \\
\text { working } \\
\text { conditions? }\end{array}$ & $\begin{array}{l}\text { - Mostly unanswered } \\
\text { - Less duration of program can be } \\
\text { a problem which need to be ad- } \\
\text { dress administratively }\end{array}$ \\
\hline 65 & Other comments & \\
\hline
\end{tabular}

This study found 38.3 OSI score among students in King Abdul Aziz University. Less work pressure, low working experience, summer holidays, regular monthly stipend, fewer responsibilities, relaxing exams schedule, less number of days spent weakly are all reason for low OSI score.

Problems at work and decision making at work variables were the main contributor for OSI score. Problems at work related questions mainly discuss about the work related information and decision at work questions is related to responded involvement in the 
decisions making.

For open-ended questions about student's current work, the answers are shown in table 3 as follows.

Physical working conditions were not contributing much in OSI. Only the absence of fixed position due to involvement in lab work is the main contributor factor. As academic occupation, there is no accident or injury contribution for OSI score. There is no certain changes found in the work recently as a continuous and similar routine just $2.6 \%$ OSI score found in total OSI score. The limited number of sample size and inclusion of only international students are the limitations of this study.

\section{Conclusion}

This study reveals low Occupational Stress Index score (OSI) among international students. This low OSI score can be attributed toward low work pressure, good working environment and good facilities in university. Main stressors are problems at work, language barrier, and scarcity of funding for $\mathrm{PhD}$ research. This study will contribute in highlight the main stress factors among students. By virtue of it, scientific community will get insight into university students stress factors. Also for university management it will helpful in managing students problems so that they can take part in academic, research activities with zeal and zest and can prove themselves as productive researchers.

\section{Limitations}

As sample was only international students, which seems to be a small sample size and cannot be considered as a representative sample for all students. So there is a ground for estimating occupational stress score for all students with large sample size. Other parameters like occupational stress indicator can also be added. The same study should also be conducted for academic and non-academic staff of the university.

\section{References}

Belkić, K., Savić, Č., Theorell, T., Rakić, L., Ercegovac, D. and Djordjević, M. (1994) Mechanisms of cardiac risk in professional drivers, Scand J Work Environ Health, 20: 73-86.

Belkić, K., Savić, Č., Djordjević, M., Uglješić, M. and Micković, L. (1992) Event-related potentials in professional drivers: heightened sensitivity to cognitively relevant visual signals, Physiol Behav, 52: 423-7.

Emdad R, Belkić K, Theorell T. and Cizinsky S. (2009) What prevents professional drivers from following physicians' cardiologic advice? Psychother Psychosom. 67: 226-40.

Moller, R. A. (2005) Conceptualization of driving behaviour as threat avoidance, Ergonomics, 27: 1139-55.

Israel, B. A., Goldenhar, L., Baker, E. A. and Heaney, C. A. (1996) Occupational stress, safety and health: conceptual framework and principles for effective prevention interventions, J Occup Health Psychol, 1: 261-86.

Karasek, R. and Theorell, T. (2012) "Healthy work: stress, productivity and the reconstruction of working life" New York (NY): Basic Books; 1990.

Latif, M. d. A. and Sultana, S. (2009) Adaptation of an occupational stress index, J. Life Earth Sci, 3-4: 55-57.

Möller, J., Theorell, T., de Faire, U. and et al. (2005) Work related stressful life events and the risk of myocardial infarction. Case-control and case-crossover analyses within the Stockholm heart epidemiology programme (SHEEP), J Epidemiol Community Health, 59: 23-30.

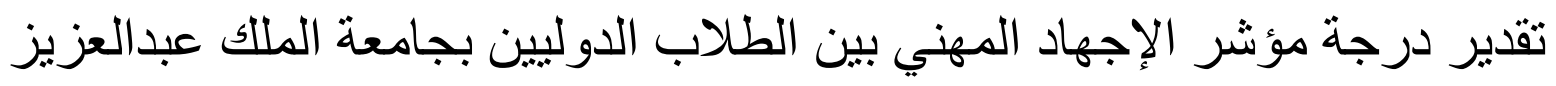


محسن عباس، وإعجاز أحمد، ومنصور أحمد بالخيور

قسم العلوم البيئية، كلية الأرصاد والبيئة وزراعة المناطق الجافة، جلة، المدلكة العربية السعودية

المستخلص: الإجهاد هو طريق الجسم للاستجابة لأي نوع من الطلب أو التهديد. ويمكن أن يبدأ ببساطة

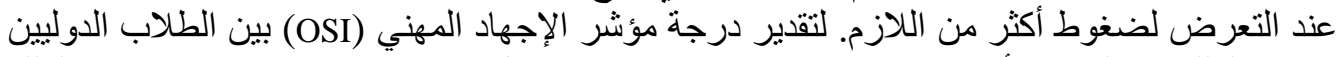

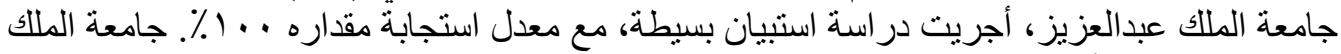

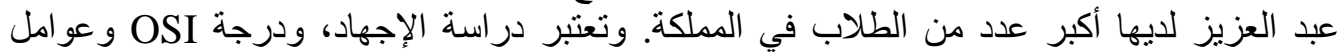

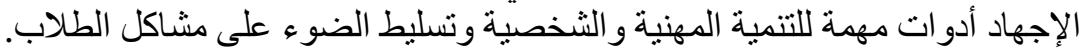

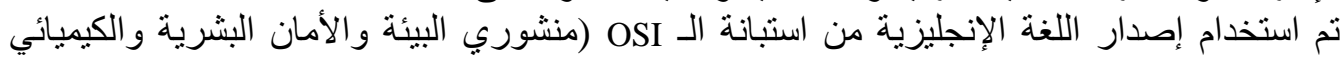
CHS M278/EHS M270

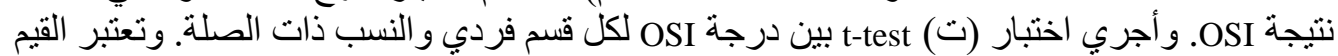

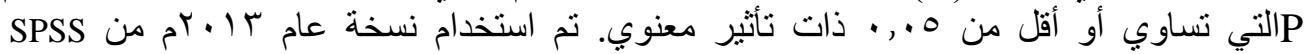
Microsoft Excel و تلنحليل البيانات.

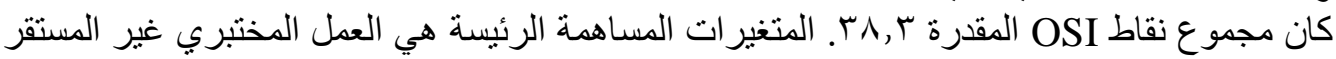

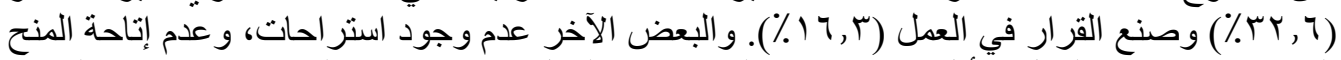

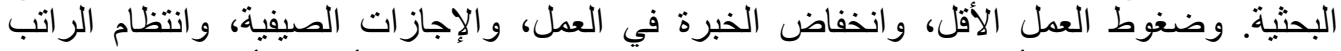

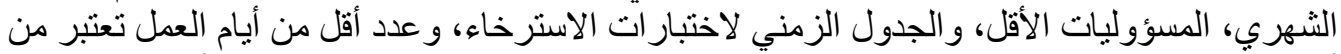

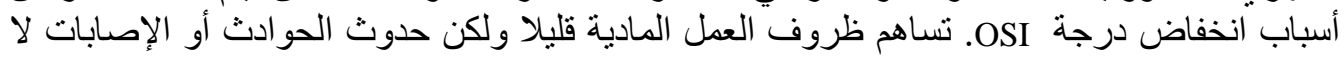

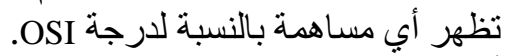
أثبتت درجة OSI المنخفضة لطبة لطاب جامعة الملك عبدالعزيز الدوليين أنهم بعملون في بيئة مريحة

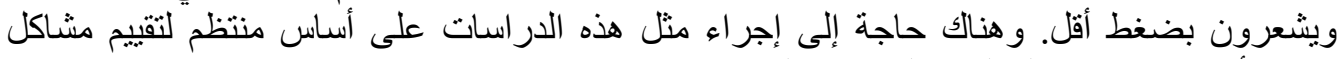
طلاب أكبر جامعة في المملكة و التحديات التي يو اجهونها. 